\title{
Marker-free PLRV resistant potato mediated by Cre-loxP excision and RNAi
}

\author{
Jeanette Orbegozo • Dennis Solorzano • Wilmer J. Cuellar • Ida Bartolini • \\ Maria Lupe Roman • Marc Ghislain · Jan Kreuze
}

Received: 22 March 2016/Accepted: 5 August 2016/Published online: 20 August 2016

(C) The Author(s) 2016. This article is published with open access at Springerlink.com

\begin{abstract}
An inverted repeat construct corresponding to a segment of the potato leaf roll virus coat protein gene was created under control of a constitutive promoter and transferred into a transformation vector with a heat inducible Cre-loxP system to excise the nptII antibiotic resistance marker gene. Fifty-eight transgenic events were evaluated for resistance to PLRV by greenhouse inoculations, which lead to the identification of 7 highly resistant events, of which 4 were extremely resistant. This resistance was also highly effective against accumulation in subsequent tuber generations from inoculated plants, which has not been reported before. Northern blot analysis showed correlation of PLRV specific siRNA accumulation with the level of PLRV resistance. Heat
\end{abstract}

Electronic supplementary material The online version of this article (doi:10.1007/s11248-016-9976-y) contains supplementary material, which is available to authorized users.

J. Orbegozo · D. Solorzano - W. J. Cuellar ·

I. Bartolini · M. L. Roman · M. Ghislain · J. Kreuze ( $₫)$

International Potato Center (CIP),

P.O. Box 1558, Lima 12, Peru

e-mail: j.kreuze@cgiar.org

M. Ghislain

CIP, P.O. Box 25171, Nairobi 00603, Kenya

Present Address:

J. Orbegozo

West University Av. C/O Veterinary Service, El Paso,

TX 79968, USA mediated excision of the nptII antibiotic resistance gene in PLRV resistant events was highly efficient in one event with full excision in $71 \%$ of treated explants. On the other hand 8 out of 10 analyzed events showed truncated T-DNA insertions lacking one of the two loxP sites as determined by PCR and confirmed by sequencing flanking regions in 2 events, suggesting cryptic LB sites in the non-coding region between the nptII gene and the flanking loxP site. Accordingly, it is proposed to modify the Cre-loxP vector by reducing the $1 \mathrm{~kb}$ size of the region between nptII, loxP, and the LB.

Keywords Potato leaf-roll virus resistance $\cdot$ Marker free $\cdot$ Cre-loxP $\cdot$ RNAi

Present Address:

D. Solorzano

Dirección de Salud (DISA) II, Ministerio de Salud, Lima 04, Peru

Present Address:

W. J. Cuellar

International Center for Tropical Agriculture (CIAT), Palmira, Colombia

Present Address:

I. Bartolini

Servicio Nacional de Sanidad Agraria (SENASA), Lima, Peru 


\section{Introduction}

Potato leaf roll virus (PLRV, Genus: Polerovirus, Family: Luteoviridae) is one of the most widespread and important virus disease in potato cultivation (Barker and Dale 2006). In nature, PLRV is obligatorily transmitted in a persistent, circulative and nonpropagative manner by aphids (Harrison 1958; Sylvester 1980) and through seed tubers, causing serious economic and yield losses in potato worldwide (Novy et al. 2007). PLRV damages of the potato crop are controlled by the use of certified seed (Radcliffe and Ragsdale 2002) and by insecticide applications (Mowry 2005). However, these techniques are not always accessible, may be also costly, in particular to small-farmers, and produce environmental and human health concerns (Paoletti and Pimentel 2000; Syller 1996; Thomas et al. 1997).

A more economic and environmentally acceptable way to control PLRV is the cultivation of potatoes with enhanced resistance (Barker and Waterhouse 1999). Immunity to PLRV in commercial cultivars has not been reported to date (Taliansky et al. 2003; Thomas et al. 1997). However, different types and sources of resistance have been used by potato breeders. The levels of resistance are classified into two modes of operation: (1) resistance against infection by viruliferous aphids; (2) and resistance to accumulation of the virus (Barker and Harrison 1986). Unfortunately, both resistances until recently were polygenic and their use in breeding programs is timeconsuming with an uncertain outcome (Barker and Dale 2006; Davidson 1973; Taliansky et al. 2003). However, a valuable source of resistance in Solanum tuberosum Andigena Group was recently found with a major QTL on chromosome V conferring resistance to PLRV and is now introgressed into advanced breeding lines by marker-assisted selection (Mihovilovich et al. 2014; Velásquez et al. 2007).

The direct transfer of PLRV resistance genes into widely grown varieties by genetic transformation presents the advantage of maintaining the variety unchanged except for the introduced trait. The use of transgenes for expression of plant virus sequences, to induce resistance (pathogen derived resistance), is one means by which the problems of complex inheritance of PLRV resistance can be overcome (Barker and Waterhouse 1999), and there are several reports on the successful application of this technology as well as commercial releases of NewLeaf varieties in the US (Barker et al. 1992, 1994; Ehrenfeld et al. 2004; Graham et al. 1997; Kawchuk et al. 1990; Thomas et al. 2000). Pathogen-derived resistance activates a natural cytoplasmic antiviral mechanism called RNA interference (RNAi). In RNAi, double-stranded RNA (dsRNA) is recognized in eukaryotic cells and cleaved by an RNase III- like ribonuclease, called Dicer, into small RNA of 21-23 bp. These small interfering RNAs (siRNAs) are loaded into an RNA-induced silencing complex (RISC) that then act as guides to recognize complementary RNA which are cleaved again (Waterhouse et al. 2001). Accordingly, the expression of dsRNA via an inverted repeat of viral sequences, separated by a spacer or intron, has been successful to generate protection against viruses by RNAi (Smith et al. 2000; Waterhouse et al. 1998). High levels of resistance in transgenic plants expressing such hairpin construct have been obtained also against potato viruses such as, Potato virus Y, Potato virus X, Potato virus A and Potato leaf roll virus (Arif et al. 2012; Bai et al. 2009; Chung et al. 2013; Missiou et al. 2004).

Furthermore, pathogen-derived resistance has the advantage of not accumulating protein or long stretches of viral RNA (as dsRNA is almost instantly degraded into siRNA). This situation avoids concerns, such as recombination, transcapsidation and synergism between a viral protein produced from a transgene, and an infected plant RNA virus which makes it attractive from a biosafety perspective (Latham and Wilson 2008; Lemgo et al. 2013).

On the other hand, the use of antibiotic resistance genes for the selection of transgenic plants has remained controversial in spite of proof of safety (Miki and McHugh 2004; Ramessar et al. 2007). The Codex Alimentarius suggested the use of alternative technologies, demonstrated to be safe, that do not rely on antibiotic resistance and other selectable markers in GMOs (Alimentarius 2003). Therefore, several alternatives have been developed in order to obtain transgenic plants free of selectable marker gene (Darbani et al. 2007; Hare and Chua 2002; Puchta 2003; Scutt et al. 2002). Among different systems, the Cre-loxP from Escherichia coli phage P1 recombination system has proven effective using a heat shock inducible promoter ( $h s p$ ) in Arabidopsis (Hoff et al. 2001), maize (Zhang et al. 2003), tobacco (Liu et al. 2005), poplar (Fladung et al. 2005) potato (Cuellar 
et al. 2006) and rice (Khattri et al. 2011). This system expresses the cre recombinase to eliminate the antibiotic resistance and the cre gene which are flanked by directly repeated loxP sites (Dale and Ow 1991; Gilbertson 2003; Hoess and Abremski 1990).

At the same time, the criteria of the Environmental Protection Agency (EPA), Food Drug Administration (FDA), United State Department of Agriculture (USDA) and other important agencies about the control and biosafety of genetically modified organism (GMO) consider that the integrity of T-DNA, insertion copy numbers, frequency of chromosomal rearrangements, the insertion sites, flanking sequences, and T-DNA preference toward particular regions of genes are knowledge required to facilitate the biological safety evaluation (Cullen et al. 2011; McHughen and Smyth 2008). These information have been described in several plants such as Arabidopsis thaliana (Hoff et al. 2001), rice (An et al. 2003), tomato (Thomas and Jones 2007), oat (Svitashev et al. 2000), cotton (Zhang et al. 2008) and potato (Cullen et al. 2011).

In this study we have used our previously developed heat inducible self-excision by Cre-loxP system of the nptII selectable maker gene and an inverted repeats of the coat protein $(\mathrm{CP})$ gene of PLRV in a hairpin (hpRNA) to obtain a marker-free transgenic plant with high level of resistance to PLRV. Additionally, we analyzed siRNA production, the T-DNA insertion copy number, the site and their flanking sequence of resistant events by using TAIL-PCR, and Genome walker amplification.

\section{Materials and methods}

Gene construct with excisable nptII gene and hairpin PLRV RNAi

A fragment of $395 \mathrm{bp}$ from the coat protein encoding sequence from PLRV (cpPLRV) 3626-4034 position of GenBank accession D13953.1 was used to construct an intron spliced hpRNA. This sequence was cloned in sense and antisense orientation, separated by the IV2 intron (217 bp; Vancanneyt et al. 1990) under the control of the Cauliflower Mosaic virus 35S promoter and CaMV35S poly-adenylation signal sequence using standard molecular techniques (Sambrook and Russell 2001). This gene cassette (referred to as
hPPLRV) was inserted into the HindIII site of the $n p t I I$ heat inducible self-excision vector pCIP33 (Cuellar et al. 2006) to produce the binary vector pCIP35 bearing a T-DNA with the hpPLRV, the nptII selectable marker gene, and the Cre-loxP excisable selectable marker system whose which complete size was 6896 bp (Fig. 1a). This plasmid was transferred into Agrobacterium tumefaciens hypervirulent strain EHA105 (Hood et al. 1993) following the protocol of electroporation (Sambrook and Russell 2001).

\section{Potato genetic transformation}

Pathogen-free plants of the potato variety 'Desiree' (accession number CIP800048) were obtained in vitro from the Gene Bank at the International Potato Center (CIP). Plantlets were cultured in liquid propagation medium (4.3 g/L Murashige and Skoog (MS) salts, $0.4 \mathrm{mg} / \mathrm{L}$ thiamine, $2 \mathrm{mg} / \mathrm{L}$ glycine, $0.5 \mathrm{mg} / \mathrm{L}$ nicotinic acid, $0.5 \mathrm{mg} / \mathrm{L}$ pyridoxine, $0.1 \mathrm{mg} / \mathrm{L}$ gibberellic acid, $2 \%$ sucrose, and $\mathrm{pH} 5.6$ ) during 4 weeks in a growth room at $14-16{ }^{\circ} \mathrm{C}, 70 \%$ relative humidity, and $16 \mathrm{~h}$ photoperiod (2,000 lux).

In parallel, A. tumefaciens carrying the plasmid pCIP35 was cultivated on Luria-Bertani (LB; $1 \%$ bacto-tryptone, $0.5 \%$ yeast extract, $1 \% \mathrm{NaCl}, \mathrm{pH} 7.5$, and $2.5 \mathrm{~g} / \mathrm{L}$ of agar) supplemented with $100 \mathrm{mg} / \mathrm{L}$ kanamycin at $28{ }^{\circ} \mathrm{C}$ for $48 \mathrm{~h}$. A single bacterial colony was used to inoculate $3 \mathrm{ml}$ of liquid media LB that contained $100 \mathrm{mg} / \mathrm{L}$ kanamycin, and $100 \mathrm{mg} / \mathrm{L}$ rifampicin at $28{ }^{\circ} \mathrm{C}$ for $20 \mathrm{~h}$ in a water bath shaker $(250 \mathrm{rpm})$. Leaves with the petiole $(1.5-2 \mathrm{~cm})$ were cut from the top third of the in vitro plantlets and cocultivated with $A$. tumefaciens at a final concentration of $5 \times 10^{7}$ cells $/ \mathrm{ml}$ (bacterial concentration was estimated from standard curve by absorbance at $620 \mathrm{~nm}$ ) in $25 \mathrm{ml}$ of co-culture medium $(4.6 \mathrm{~g} / \mathrm{L}$ of MS salts, $2 \%$ sucrose, and $50 \mu \mathrm{M}$ acetosyringone) at $22{ }^{\circ} \mathrm{C}$ for $24 \mathrm{~h}$ in dark. The explants were then taken out from liquid medium and briefly dried on sterile filter paper before transferring them to semi-solid regeneration medium $(4.6 \mathrm{~g} / \mathrm{L}$ MS salts, $0.02 \mathrm{mg} / \mathrm{L}$ gibberellic acid, $0.02 \mathrm{mg} / \mathrm{L}$ naphthalene acetic acid, $2 \mathrm{mg} / \mathrm{L}$ zeatin riboside, $2 \%$ sucrose, $\mathrm{pH} 5.6$ and $4 \mathrm{~g} / \mathrm{L}$ of agar) without antibiotic for one day. Subsequently they were transferred (ten leaves per petri dish) to semi-solid regeneration medium containing $100 \mathrm{mg} / \mathrm{L}$ kanamycin and $200 \mathrm{mg} / \mathrm{L}$ carbenicillin and transferred onto fresh medium every 2 weeks. After one month 

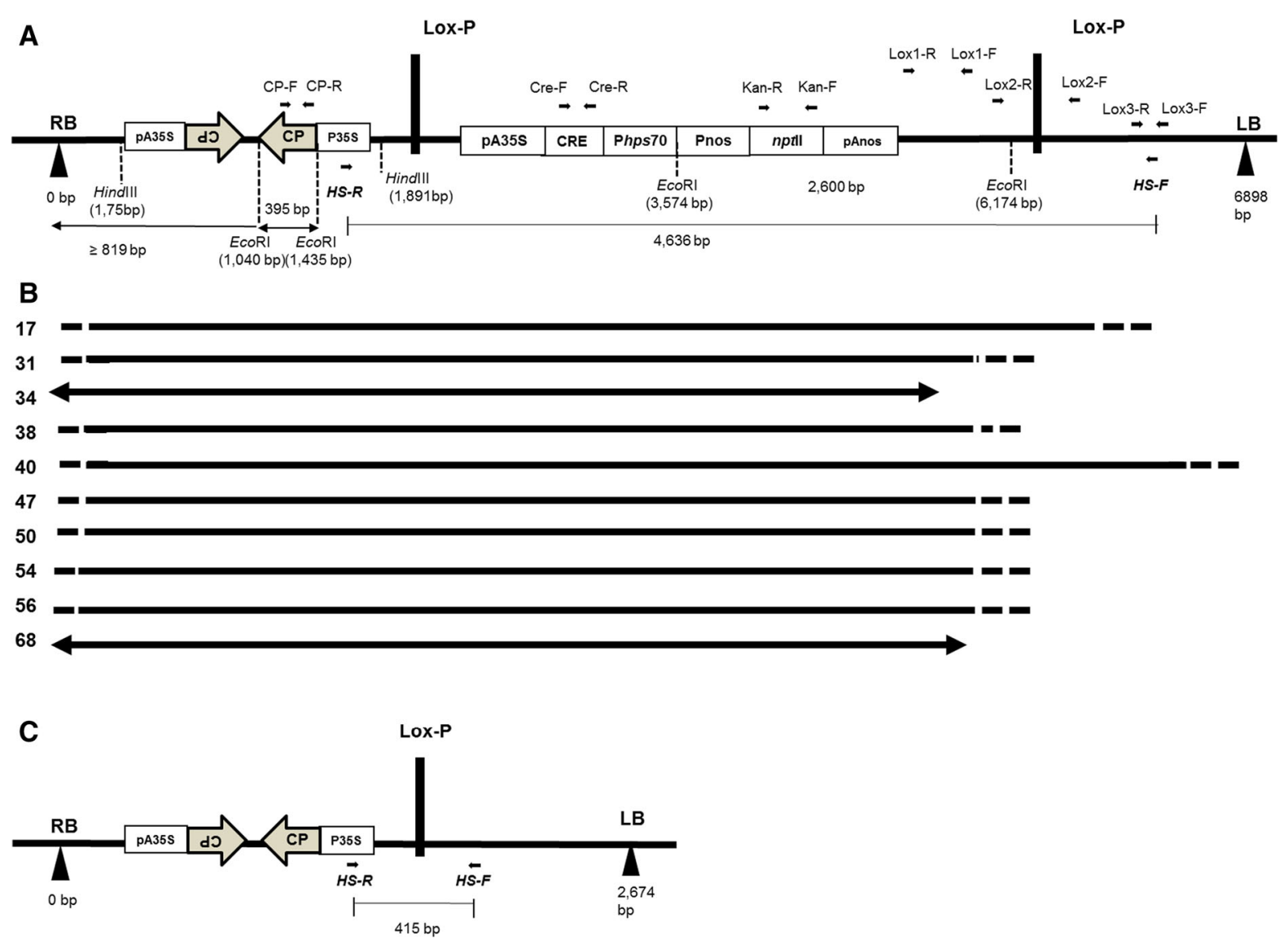

Fig. 1 Schematic diagram of the T-DNA region of the pCIP35 carrying the inverted-repeat sequence of CP-PLRV and CreloxP excisable system under heat-inducible control. a T-DNA of $6896 \mathrm{bp}$ from left to right: $\mathrm{RB}$ right border; pA35S is the CaMV35S poly-adenylation signal sequence; coat protein $(\mathrm{CP})$ gene of PLRV (395 bp) with inverted repeat separated by the IV2 intron; P35S CaMV35S promoter; loxP represents the recombination sites; CRE represents cre recombinase gene; $\mathrm{Phps} 70$ is the heat-inducible promoter; Pnos is the nos promoter; $n p t$ II represents the antibiotic resistance gene used a selectable marker; pAnos is the nos poly-adenylation signal sequence; LB, left border. HindIII and EcoRI are restriction sites

regenerants started to appear from Agrobacteriuminfected leaf explants, and putative transgenic regenerants (only one regenerant per explant) were screened by PCR to detect cpPLRV (CP-F/R), nptII (Km-F/R), and cre recombinase $(\mathrm{Cre}-\mathrm{F} / \mathrm{R})$ genes respectively after 6 weeks of growth. The regenerants were propagated in test tubes containing semi-solid regeneration medium at $15-18{ }^{\circ} \mathrm{C}$ under artificial light $(16 \mathrm{~h}$ light/ $8 \mathrm{~h}$ dark). Individual transgenic events were designated as CIP35-[n]. The regeneration efficiency (\%) was calculated as the number of regenerated shoots with position relative to first nucleotide of the RB, indicated by dotted line. Approximate positions of amplification primers are indicated by short thick arrows. The thin arrow bands indicate the minimum size of the positive band by Southern blotting using conditions described in materials and methods. The thin line flanked by HS-F/HS-R primers indicates the expected amplicon including the Cre-loxP self-excisable system. b The lines with dashed ends indicate the approximate inserted fragment of T-DNA as determined by PCR for each event as indicated to the left. Arrowheads indicate exact position of fragment ends were determined by sequencing. c T-DNA structure after successful excision of the nptII gene

over the number of Agrobacterium-infected explants. Transformation efficiency (\%) was based on the number of PCR and Southern blot positive plants over the number of Agrobacterium-infected explants.

The leaves from the putative transgenic regenerants were confirmed to be transgenic on a highly selective medium. Leaves were laid on kanamycin selective callus-inducing medium (4.6 g/L MS salts, $20 \mathrm{~g} / \mathrm{L} \mathrm{D-}$ mannitol, $0.5 \mathrm{~g} / \mathrm{L} 2$-( $N$-morpholino)-ethane sulfonic acid, $0.5 \mathrm{~g} / \mathrm{L}$ polyvinylpyrrolidone (40,000), $200 \mathrm{mg} /$ L L-glutamine, $\quad 40 \mathrm{mg} / \mathrm{L}$ adenine, $0.1 \mathrm{mg} / \mathrm{L}$ 
naphthalene acetic acid, $0.1 \mathrm{mg} / \mathrm{L}$ 6-benzylaminopurine, $0.5 \mathrm{mg} / \mathrm{L}$ nicotinic acid, $0.5 \mathrm{mg} / \mathrm{L}$ pyridoxine, $2 \mathrm{mg} / \mathrm{L}$ glycine, $2 \%$ sucrose, adjusted to $\mathrm{pH} 5.8$, and $2 \mathrm{~g} / \mathrm{L}$ gelrite). Then, the sterilized medium was supplemented with $1 \mathrm{mg} / \mathrm{L}$ zeatin riboside, $0.1 \mathrm{mg} / \mathrm{L}$ naphthalene acetic acid and $200 \mathrm{mg} / \mathrm{L}$ kanamycin. Untransformed potato leaf from the varieties 'Desiree' were included as controls. After one month, callus appeared only from positive transgenic events.

Plant nucleic acid isolation

For DNA isolation, we used $4 \mathrm{~g}$ of fresh leaf tissue ground in liquid nitrogen. The fine powder was transferred into tubes with $20 \mathrm{ml}$ of CTAB extraction buffer $(100 \mathrm{mM}$ Tris-HCl, $25 \mathrm{mM}$ EDTA, $1.4 \mathrm{M}$ $\mathrm{NaCl}$ and $2 \% \mathrm{CTAB}$ ) and $200 \mu \mathrm{l}$ of 2-mercaptoethanol and incubated at $65{ }^{\circ} \mathrm{C}$ in a water bath for $20 \mathrm{~min}$, and cooled down to room temperature (RT) for $10 \mathrm{~min}$. Then, $20 \mathrm{ml}$ of chloroform: isoamyl alcohol (24:1) was added, and mixed gently for $5 \mathrm{~min}$. The extract was centrifuged at 5,000 rpm for $20 \mathrm{~min}$. The upper phase was transferred to a clean $50 \mathrm{ml}$ tube, and this step was repeated one more time. Then $15 \mathrm{ml}$ of cold isopropanol was added and mixed well by inversion, and incubated at $-20{ }^{\circ} \mathrm{C}$ for $1 \mathrm{~h}$, or $-70{ }^{\circ} \mathrm{C}$ for $30 \mathrm{~min}$. Precipitated DNA was centrifuged at $5000 \mathrm{rpm}$ for $20 \mathrm{~min}$. The supernatant was discarded and the pellet left drying out for $5 \mathrm{~min}$. The precipitated DNA was transferred into a clean standard $1.5 \mathrm{ml}$ microtube, washed by adding $300 \mu \mathrm{l}$ of washing solution I $(\mathrm{EtOH} 75 \%$ and sodium acetate $0.2 \mathrm{M}$ ), and left at room temperature for $10 \mathrm{~min}$. Finally, the DNA was transferred into a clean standard $1.5 \mathrm{ml}$ microtube, washed with $300 \mu \mathrm{l}$ of washing solution II (EtOH $75 \%$ and $10 \mathrm{mM}$ ammonium acetate), and left at room temperature for $1 \mathrm{~min}$. The pellet was then dissolved in $100 \mu \mathrm{l}$ of Nuclease-free water and treated with $1 \mu \mathrm{l}$ of $10 \mathrm{mg} / \mathrm{ml}$ RNAse for $15 \mathrm{~min}$ at $37^{\circ} \mathrm{C}$. The quality of the DNA extractions was confirmed under UV light by standard TBE agarose gel electrophoresis (1\%) and staining with ethidium bromide. Concentration and purity of nucleic acids were estimated by measuring $\mathrm{A}^{260}$ and $\mathrm{A}^{280}$ values with a UV spectrophotometer (Sambrook and Russell 2001).
PCR assay

We designed seven primer pairs in order to amplify various regions of the T-DNA (Table 1). PCR was performed using $1 \mu \mathrm{l}$ of DNA $(100 \mathrm{ng} / \mu \mathrm{l})$ with the following reagents: $1.5 \mu \mathrm{l}$ PCR $10 \times$ standard Taq Reaction Buffer (10 mM Tris- $\mathrm{HCl}, 50 \mathrm{mM} \mathrm{KCl}$, $1.5 \mathrm{mM} \mathrm{MgCl} 2, \mathrm{pH} 8.3$ at $25^{\circ} \mathrm{C}$ ), $0.5 \mu \mathrm{l}$ dNTPs $(5 \mathrm{mM}), 0.75 \mu \mathrm{l}$ each of the PCR primers $(50 \mu \mathrm{M})$, $10 \mu \mathrm{l}$ water and $0.5 \mu \mathrm{l} \mathrm{Taq}$ DNA Polymerase (5000 units/ml Bio Labs). PCR amplification conditions were optimized with an initial denaturation at $94{ }^{\circ} \mathrm{C}$ for $1 \mathrm{~min}$ followed by 35 cycles of $1 \mathrm{~min}$ at $94^{\circ} \mathrm{C}$, the annealing temperature varied according to the primer combination used for $50 \mathrm{~s}$ and $72{ }^{\circ} \mathrm{C}$ for $1.2 \mathrm{~min}$. Finally, an extension time was added at $72{ }^{\circ} \mathrm{C}$ for $7 \mathrm{~min}$, and the PCR reaction was then stored at $4{ }^{\circ} \mathrm{C}$. PCR reactions $(15 \mu \mathrm{l})$ were analyzed by agarose gel electrophoresis as described above.

\section{Southern blotting hybridization}

Genomic DNA $(15 \mu \mathrm{g})$ was digested with EcoRI (20 units) in $150 \mu \mathrm{l}$ reaction volume, at $37^{\circ} \mathrm{C}$ overnight. DNA fragments were separated on a $0.8 \%$ agarose gel electrophoresis overnight, and transferred to nylon membranes (Hybond-N+, Amersham) by capillary transfer according to Sambrook and Russell (2001). DNA fragments were bound to the membrane by UV cross- linking (Southern Stratalinker 2400). cpPLRV gene (279 bp) was used as probe labeled with [ $\alpha 32$ ] $\mathrm{dCTP}$ using the Gene Images Random Prime Labeling kit according to the manufacturer's recommendation. The probes were hybridized with the membranes at $65^{\circ} \mathrm{C}$ for $18 \mathrm{~h}$. The hybridized filter was washed with $1 \times$ SSC, $0.1 \%$ SDS (w/v) and $0.5 \times$ SSC, $0.1 \%$ SDS $(\mathrm{w} / \mathrm{v})$ at $65{ }^{\circ} \mathrm{C}$ for $15 \mathrm{~min}$ with gentle agitation. The blot was wrapped in a polyethylene sheet and exposed to radiographic film (Kodak). To detect excision events, we used as probe the nptII gene (638 bp) labeled with PCR DIG Synthesis (Roche kit) according to the manufacturer's conditions. The probe was hybridized at $65{ }^{\circ} \mathrm{C}$ for $30 \mathrm{~min}$ with $15 \mathrm{ml}$ of DIG Easy Hyb solution (Roche kit) at $25 \mathrm{ng} / \mathrm{mL}$. The membrane was washed using stringent conditions and exposed to X-ray film (Kodak) at room temperature for $16 \mathrm{~h}$. 
Table 1 Primer sequences their respective annealing temperature $\left(\mathrm{T}_{\mathrm{a}}\right)$ and product size (bp)
CP-F/R and KM-F/R were used for amplifying the probe for Southern blotting. The HS-F/R produced two amplicon sizes depending on successful excision event

\begin{tabular}{|c|c|c|c|}
\hline Primer & Sequences & $\mathrm{T}_{\mathrm{a}}\left({ }^{\circ} \mathrm{C}\right)$ & Product size (bp) \\
\hline $\mathrm{CP}-\mathrm{F}$ & 5'-GAAGACGTAGAAGAGGAGGCAA-3' & 60 & 279 \\
\hline $\mathrm{CP}-\mathrm{R}$ & 5'-TGCAATGGGGGTCCAACTCATAA-3' & & \\
\hline Kan-F & 5'-CAGCAATATCACGGGTAGCCA-3' & 56 & 638 \\
\hline Kan-R & 5'-GGCTATTCGGCTATGACTGGG-3' & & \\
\hline Cre-F & 5'-GCGCGGTCTGGCAGTAAAAA-3' & 54 & 751 \\
\hline Cre-R & $5^{\prime}$-ACTATCTAGATTACGGATAT $-3^{\prime}$ & & \\
\hline Lox $1-\mathrm{F}$ & 5'-GACATTCAACCGATTGAGGG-3' & 55 & 774 \\
\hline Lox $1-\mathrm{R}$ & 5'-CGACTGCCCAGGCAAGACCG-3' & & \\
\hline Lox $2-\mathrm{F}$ & 5'-GGATGTGCTGCAAGGCGATTA-3' & 54 & 572 \\
\hline Lox2-R & 5'-GCTACTGATTACGGTGCTGC-3' & & \\
\hline Lox3-F & 5'-CGAACGTGGCGAGAAAGGAAG-3' & 54 & 110 \\
\hline Lox3-R & 5'-AGCTGGCGTAATAGCGAAGA-3' & & \\
\hline HS-F & $5^{\prime}$-GAACGTGGCGAGAAAGGAAGG-3' & 56 & $4,636 / 415$ \\
\hline HS-R & $5^{\prime}$-TCGATGAAGTGACAGATAGCTGG-3' & & \\
\hline
\end{tabular}

PLRV resistance assays

Transgenic events and a non-transgenic control were transferred to the biosafety greenhouse to acclimatize and produce tubers. Plants were grown from four tubers from each transgenic event. Thirty days after planting, these events were inoculated by grafting with PLRV infected Flor Blanca scions (Peruvian cultivar highly susceptible to PLRV), or for the case of the noninoculated control with healthy Flor Blanca. The grafts were secured with Parafilm M (Sigma), and the whole plants were covered with a thin transparent plastic bag to avoid dehydration of the scions. The bag was removed 5 days after grafting. The controls were a non-transgenic Desiree inoculated similarly (positive control), and a mock-inoculated transgenic health plant (negative control). All plants were left to produce tubers and one tuber from each plant was then planted after breaking of dormancy to evaluate resistance to secondary infection. Symptoms were monitored throughout the growing period and scored on a scale from 0 to $2(0=$ no symptoms, $1=$ mild symptoms, and $2=$ severe symptoms). Based on the results, 10 transgenic events were selected for a repeated experiment, which was carried out as described above, except that 15 plants per event were evaluated.

Quantification of PLRV by immunological assay

Detection of PLRV in inoculated plants was performed by double antibody sandwich enzyme-linked immunoabsorbent assay (DAS-ELISA). Virus-specific polyclonal antibodies (dilution, 1:1000) to the coat protein of PLRV, and the specific alkaline phosphatase conjugated polyclonal antibodies (dilution, 1:1000) were provided by the Laboratory of Virology at CIP. Absorbance at $405 \mathrm{~nm}$ was used to quantify PLRV, 15-30 min after adding the substrate ( $p$-nitrophenyl phosphate) according to manufacturers' instruction of the alkaline phosphatase substrate kit (Bio-Rad), using a microplate reader Bio-Rad 550 (Bio-Rad). A plant was considered infected if the absorbance was higher than the average of the non-infected control plus two times the standard deviation. Results were subjected to statistical analysis using the non-parametric KruskalWallis test (Kruskal and Wallis 1952). The presence of virus was determined at 30,60 and 90 days after grafting (primary infection) and at 30,60 and 90 days after planting of tubers from infected plants in secondary infection. All experiments were performed using complete randomized block design, and samples were taken by combining three leaflets (top, middle, and bottom of the plant) per plant, and two individual measurements were made per sample.

Northern blotting hybridization

Leaf tissue was ground into a fine powder in liquid nitrogen and RNA was isolated with TRIzol LS Reagent (Invitrogen, Ltd.) according to the manufacturer's instructions. The low-molecular-weight (LMW) RNA fraction containing siRNA was 
separated by the $\mathrm{LiCl}_{4}$ precipitation method as described previously (Kreuze et al. 2005). To analyze siRNA, $30 \mu \mathrm{g}$ of LMW RNA was mixed with an equal volume of Tris-borate-EDTA- urea sample buffer (Bio-Rad), heated at $100{ }^{\circ} \mathrm{C}$ for $5 \mathrm{~min}$ and separated on a $15 \%$ polyacrylamide Tris-borate-EDTAurea gel and blotted to a nylon membrane (HybondNX, Amersham). The radiolabeled RNA probe was hybridized overnight, then the membrane was washed three-time with $5 \times \mathrm{SSC}, 0.1 \% \mathrm{SDS}(\mathrm{w} / \mathrm{v})$ at $37{ }^{\circ} \mathrm{C}$ for $15 \mathrm{~min}$ with gentle agitation. The membrane was UV cross-linked as described above, the blots were wrapped in a polyethylene sheet and exposed to a radiographic film (Kodak). Sense and antisense [a32P] UTP labeled RNA probes complementary to CP transgene were synthesized with T7 RNA polymerase (Promega, Madison, WI, USA) using the plasmid pGEM $^{\circledR}-\mathrm{T}$ Easy linearized with NdeI. For the hybridization with siRNA, the probe was denatured by alkaline hydrolysis in carbonate buffer $(120 \mathrm{mM}$ $\mathrm{Na}_{2} \mathrm{CO}_{3}, 80 \mathrm{mM} \mathrm{NaHCO} 3, \mathrm{pH} 10.2$ ) to obtain fragments of an average length of $50 \mathrm{bp}$ and then hybridized, washed and developed as described by Kreuze et al. (2005). A control sample of siRNA for the hpPLRV was prepared as follows. The Agrobacterium tumefaciens bearing the hpPLRV construct was grown overnight at $28{ }^{\circ} \mathrm{C}$ in $100 \mathrm{ml}$ of liquid medium LB containing $100 \mathrm{mg} / \mathrm{L}$ kanamycin and $50 \mathrm{mg} / \mathrm{L}$ rifampicin. The bacterial cells were harvested by centrifugation at room temperature at $4000 \mathrm{rpm}$ for $20 \mathrm{~min}$. Then, these were suspended in a buffer solution (10 $\mathrm{mM} \mathrm{MgCl}_{2}$ and $150 \mu \mathrm{M}$ acetosyringone). The suspension of cells was 0.5 of optical density (OD) at $600 \mathrm{~nm}$. After, this mix was left at room temperature for $3 \mathrm{~h}$ without shaking. The agroinoculation was pressure-infiltrated on the underside of the leaves of the wild type Nicotiana benthamiana cv. using a 2-ml syringe without needle. Three days later, we collected the leaf to isolated siRNA, this sample was used as positive control in the northern blot.

Excision of the nptII gene by heat treatments

Leaves with petioles and stem internodes of transgenic plants were excised and placed on semi-solid regeneration medium without antibiotic selection. Then, these petri dishes were transferred into an incubation oven at $42{ }^{\circ} \mathrm{C}$ for $3 \mathrm{~h}$ in the dark as described by Cuellar et al. (2006). The explants were then cultivated at $18-23{ }^{\circ} \mathrm{C}$ with a photoperiod of $16 \mathrm{~h}$ light $/ 8 \mathrm{~h}$ dark on same medium. As control, leaf and internodes of the same events without heat shock treatment were included. The regenerated shoots obtained were transplanted in tubes containing semi-solid regeneration medium without kanamycin. In order to select the transgenic events which lost the nptII gene by excision, we evaluated them using the kanamycin selective callus-inducing medium as described above.

Identification of T-DNA genomic flanking sequences

We used two methods to characterize the sequences surrounding the extremity of the T-DNA inserts: the thermal asymmetric interlaced PCR (TAIL-PCR); and the genome walker technique of Clontech. The modified thermal asymmetric interlaced (mTAIL)PCR protocol as described by Sessions et al. (2002) was used to amplify regions flanking of the T-DNA right border (RB) by PCR. We used the following nested specific primers and their respective Tm: RB-1, (5'-CAA ATC ACC AGT CTC TCT CTA CAA ATC TAT CTC TC- $\left.3^{\prime}\right)$ with Tm of $65^{\circ} \mathrm{C}$; RB2 $\left(5^{\prime}\right.$-CAG AAT AAT GTG TGA GTA GTT CCC AGA TAA GG-3 $\left.{ }^{\prime}\right)$ and $64{ }^{\circ} \mathrm{C}$ and RB-3 (5'-GTT CTT ATA GGG TTT CGC TCA TGT GTT GAG- $\left.3^{\prime}\right)$ and $66^{\circ} \mathrm{C}$. Each one of the two-rounds of mTAIL PCR cycling was performed in MJ Research PTC-200 Thermo Cycler (BC-MJPC200) using Go-Taq polymerase (5 U/ $\mu \mathrm{l})$ (Promega), and $5 \mathrm{ng}$ of genomic DNA.

In order to amplify regions flanking of the T-DNA left border, we developed three libraries of DNA (100 ng/ $\mu \mathrm{l})$ using DraI (10 units/ $\mu \mathrm{l})$, EcoRV (10 units/ $\mu \mathrm{l})$, and $P v u \mathrm{II}(10 \mathrm{units} / \mu \mathrm{l})$ enzymes. The ends of the genomic digested fragments were linked with two adaptors (Adaptor Primer 1: 5'-GTA ATA CGA CTC ACT ATA GGG C-3', and Nested Adaptor Primer 2: 5'-ACT ATA GGG CAC GCG TGG T-3'). PCR conditions followed the protocol of Genome Walker ${ }^{\mathrm{TM}}$ Universal kit (Clontech), and used PfuUl$\operatorname{tra}^{\mathrm{TM}}$ II Fusion HS DNA Polymerase (Stratagene). The gene specific primers were derived from sequences close to the end of the known left border (LB) sequence: LB-1 (5'-GTG TCA TCT ATG TTA CTA GAT CGG GCC TCC- $3^{\prime}$ ) with Tm of $67^{\circ} \mathrm{C}$; LB2 (5'-GCT ACT GAT TAC GGT GCT GCT ATC GAT GGT-3') and $68{ }^{\circ} \mathrm{C}$; LB-3 (5'-CGG TGA CGG TGA TAA TTC AC- $\left.3^{\prime}\right)$ and $57^{\circ} \mathrm{C}$; and LB-4 (5'-CCC 
TCA ATC GG TTG AAT GTC- $3^{\prime}$ ) and $59{ }^{\circ} \mathrm{C}$. PCR amplifications were performed using MultiGene Thermal Cycler TC9600-G (LabNet).

PCR products were purified from gel using the Wizard gel extraction kit (Promega) according to the manufacturer's instructions, and sent for sequencing to Macrogen (Korea) with the corresponding PCR primers. Similarity searches for the identified sequences were done by using BLAST at the National Center for Biotechnology Information (http://www. ncbi.nlm.nih.gov).

\section{Results}

Hairpin PLRV gene construct with excisable $n p t I I$ gene

We chose a fragment of the coat protein gene of PLRV which showed 97-100\% identity with sequences available in the genebank, including isolates from France (Accession number AF453390.1), Spain (Accession number 453393.1); Zimbabwe (Accession number AF453388.1), Peru (AF453392.1) and China (Accession number AY079210.1). It confirmed the high level of conservation of this gene among isolates from geographically distant locations. Moreover, this sequence had 80-90 \% similarity with other members from Luteoviridae family such as Barley Yellow Dwarf Virus (Accession number X17259.1), Cereal Yellow Dwarf Virus (Accession number AF235168.2), Soybean Dwarf Virus (Accession number DQ145545.1). Thus, a hairpin gene construct using this cpPLRV sequence was designed, and inserted into the corresponding sites of $\mathrm{pCIP} 33$ vector to produce the binary vector pCIP35 which contained the kanamycin selection marker gene and the Cre-loxP excisable selectable marker system. The correct position and size of several genes from T-DNA were evaluated using four restriction enzymes (BamHI, EcoRI, HindIII, and NheI), each generating characteristic fragments of the expected sizes (data not shown).

Genetic transformation and analysis of regenerants

160 potato plants explants were transformed by $A$. tumefaciens with the pCIP35 vector binary, from which 102 explants yielded calli leading to the isolation of 85 regenerated shoots. However, only 55 were positive by kanamycin selective callus-inducing medium with highly selective conditions and by PCR using specific primers to the cpPLRV, nptII, and cre genes (Fig. 1a). The regeneration efficiency was thus $53 \%$ and transformation efficiency was $34 \%$. Regenerated potato plants showed no visible phenotypic alteration due to the insertion of PLRV coat protein gene.

Virus resistance in transgenic plants following PLRV infection

Out of the 55 transgenic events transferred to the greenhouse, 53 produced sufficient tubers to perform the PLRV inoculation experiment. Four replicates of each of the 53 events were evaluated for resistance to PLRV by performing DAS-ELISA tests at 30,60 and 90 days post inoculation. We identified four events that never provided a positive result indicating the presence of PLRV in any of the replicates or time points. However, we found that the number of plants testing negative for PLRV in all the 4 replicates of transformed events increased over time: at 30,60 and 90 days: the number of events testing negative by DAS-ELISA were 11,18 and 41 respectively. One tuber per inoculated plant was planted to evaluate resistance to secondary infection by DAS-ELISA at 30, 60 and 90 days after planting. DAS-ELISA results from secondary infection resulted in a larger number of positive samples, and the tendency to recover from infection as found in primary infection was not apparent, indicating that resistance was not sufficient to suppress the more severe secondary infection in the vast majority of these events. Ten events however maintained significantly reduced or negative ELISA values as compared to the control and also remained without symptoms, and were selected for re-evaluation in a second experiment using 15 plants each. All ten events $(17,31,34,38,40,47,50,54,56$ and 68) showed significantly reduced titers during primary infection mostly less than $50 \%$ of the non-transformed control. Again a clear reduction of viral titers was observed as the plants matured indicating recovery, also in the non-transgenic control (Figure S1). Symptoms of stunting and yellowing could be observed in non-transformed cv. Desiree as well as some plants of events 40, 47 and 50 which simultaneously showed the highest DAS-ELISA values among the transgenic events. During secondary infection three different symptoms and response by DAS-ELISA in transgenic 
plants were observed, when compared to the control plants. The first phenotype was that of plants susceptible to PLRV infection which developed strong virus symptoms similar to inoculated control plants and no indication of recovery (symptom severity value 2 ) but rather an increase in viral titers (events: 40, 47 and 50), plants in another category showed reduced titers and symptoms (with average symptom value 1 ; events: 17 , 31,38 ), and a third category consisted of plants that never showed titers significantly above the untransformed and uninfected control and no symptoms (symptom value 0, events: 34, 54, 56 and 68; Fig. 2a and 3). The four candidate highly resistant transgenic events showed similar results in DAS-ELISA during tertiary infection (data not shown). Average symptom severity correlated well with virus titers, and ELISA negative plants never showed any symptoms at all. The non-parametric Kruskal-Wallis test detected significant differences in virus titers between four resistant events $(34,54,56$ and 68) and non-transgenic infected control (NT+) (Fig. 2a).

\section{Analysis of T-DNA copy number}

53 transgenic events were subjected to Southern blotting. The restriction enzyme EcoRI cuts four times within the T-DNA of pCIP35 (Fig. 1a). The cpPLRV probe hybridized to at least two fragments: (1) a small fragment of $395 \mathrm{bp}$; and (2) a second fragment of variable size and number which gives an estimate of the T-DNA copy number Fig. 1a. Accordingly, we determined the number of T-DNA inserts to be from 1 to 8 in the 53 transgenic events (data not shown). The band patterns were distinct for each transgenic event which indicated that these were the result of independent transformation occurrences. Eight of the ten selected events for repeated evaluation had one copy of T-DNA whereas the event 47 had two copies and event 54 had one or two copies (Fig. 4). Transgenic event 40 did not have the small fragment suggesting an incomplete or rearranged T-DNA structure around the hairpin gene.

Detection of siRNAs in the transgenic events

The main feature of the RNAi mechanism in plants is the production of siRNA whose detection and abundance in transgenic plants may predict virus resistance (Missiou et al. 2004). The 10 transgenic events selected for re-evaluation were analyzed approximately 2 months after their transfer to the greenhouse. Northern blot analysis revealed strong hybridization signals corresponding to the size of siRNA in healthy plants of the events: $17,31,34,38,54,56$, and 68 whereas the events 47 and 50 had low levels only slightly higher than the non-transgenic un-infected plants, and event 40 showed no hybridization signal at all (Fig. 2b).

Characterization of the nptII excision via the CreloxP system

In order to determine if the ten candidate resistant events had the intact Cre-loxP and nptII structures, PCR using the primers Lox1-F/R, Lox2-F/R, and Lox3-F/R were used to amplify the loxP region near the left border (Fig. 1a). Only the events 17 and 40 were positive using Lox2-F/R and Lox 3-F/R primer pairs respectively, whereas the events 34 and 68 were PCR negative for all three primer pairs and the remaining events were PCR positive only for the Lox 1-F/R primer pairs. Hence, only the transgenic events 17 and 40 had both $\operatorname{lox} P$ sites intact, whereas the other eight transgenic events seemed to be lacking the LB proximal loxP site (Fig. 1b). In order to verify the absence of loxP site determined by the PCR analyses, we characterized the flanking sequences of two of the most resistant events through genome walking. The sequence towards the LB in the event 34 corresponded to the T-DNA until nucleotide 5448 after which the sequence showed high similarity to potato DNA (Solanum tuberosum mechanosensitive ion channel protein 1, mitochondrial-like [LOC 102600077], transcript variant X2, mRNA [Accession number XM_006358602.1] with $90 \%$ nucleotide identity). In the event 68 , sequence towards the LB corresponded to the T-DNA until nucleotide 5693 after which it showed high similarity to potato DNA ( $M y b$ gene sequence from Solanum tuberosum [Accession number XP_006355158.1] with $96 \%$ translated amino acid identity). Noteworthy, in both events the insertion has apparently occurred within a potato gene.

Heat shock treatment of the event resistant to PLRV with intact Cre-loxP nptII structure

Since the transgenic event 40 had apparently a rearrangement around the hairpin gene, produced no 

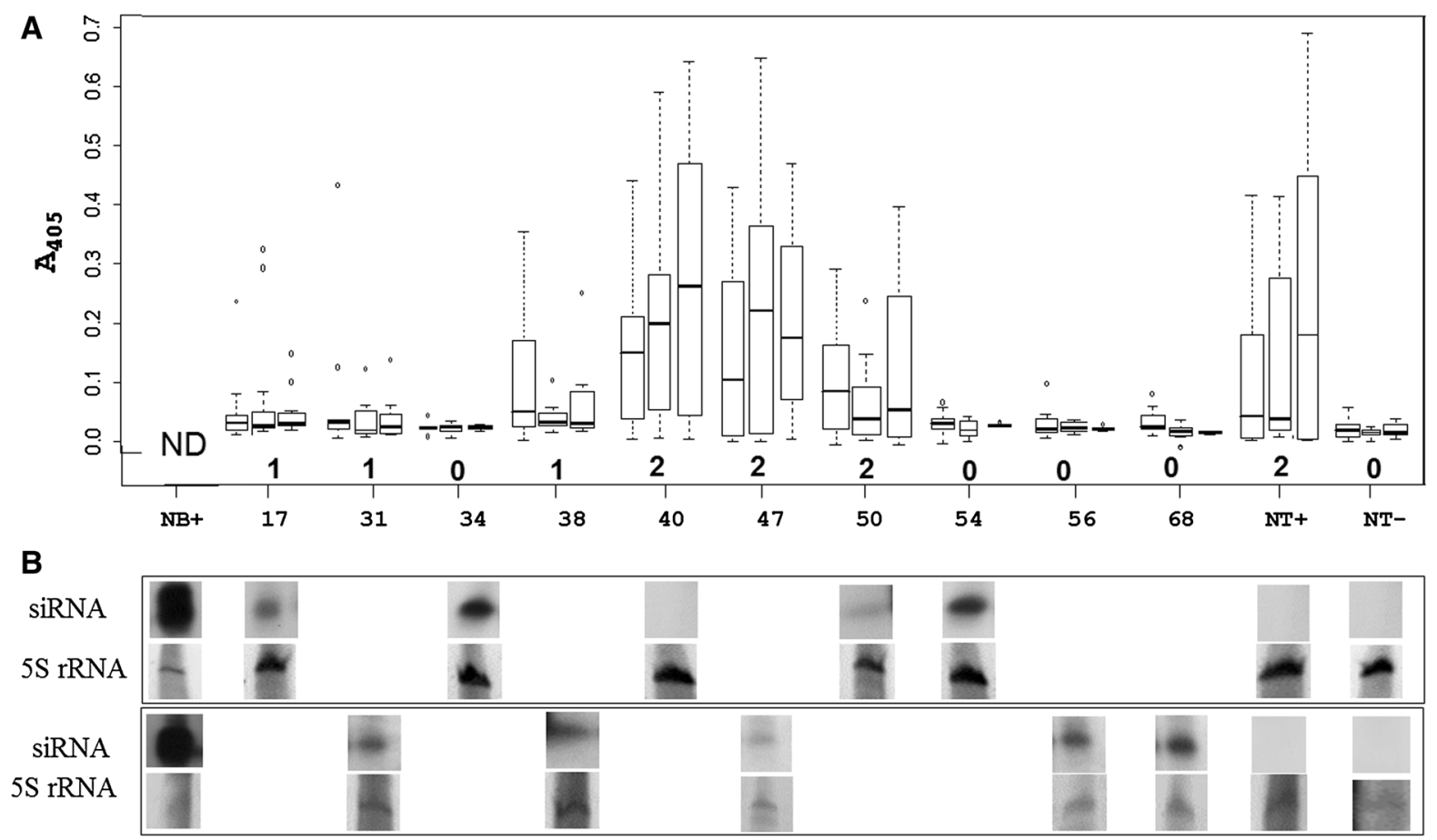

Fig. 2 DAS-ELISA and Northern blot. a Box-plot graphics showing dispersions and medians of the DAS-ELISA absorbance values $\left(\mathrm{A}_{405}\right)$ of ten transgenic events $(17,31,34$, $38,40,47,50,54,56$ and 68 ) measured at three time points (30, 60 and 90 days) after planting of tubers from PLRV inoculated mother plants. Ten transgenic events are shown at $\mathrm{x}$-axis and their absorbance values on y-axis, open dots indicate extreme values by Kruskal test.Average symptom severities are shown by numbers below each event and controls. Values were obtained from 15 individual plants (replications) of each event.

detectable siRNA whatsoever and was not resistant, we applied heat shock treatment only to the event 17 because it had an intact Cre-loxP nptII structure and was resistant to the PLRV virus. We assumed that the loxP site near the right border was complete because these events were positive in Southern blotting for the cpPLRV and PCR positive for the cre and nptII gene (Fig. 1a).

We produced a total of 1501 explants (463 petioles with leaves and 1038 stem internodes) from event 17 and exposed them to heat-shock treatment. After 2 months, we obtained 300 regenerated plants of which 140 did not form callus on kanamycin selective callus-inducing medium. Of these, we evaluated 58 plants in more detail by PCR. Out of these 41 regenerants $(41 / 58=71 \%)$ displayed a full excision as determined by PCR using HS-F/HS-R primers (Fig. 1c and S2); 12 regenerants $(12 / 58=21 \%)$
ND not done. NB+: Nicotiana benthamiana siRNA control NT-: non-transgenic healthy Desiree; NT+: non-transgenic PLRV infected Desiree. b Northern blot analysis of siRNA in ten transgenic non- inoculated lines using a probe specific to the hpPLRV and three controls. The composite figure shows siRNA hybridization signal above, and 5S RNA staining by ethidium bromide and visualized under UV light below, for each event and controls. Pictures are grouped according to two different membranes (above and below) that they were run on and are in the same order as samples in (a)

appeared to be chimeras, positive with both Cre-F/ Cre-R and HS-F/HS-R primers (Figure S3); and 5 regenerants $(5 / 58=8 \%)$ did not appear to have had any excision at all being positive with only the Cre-F/ Cre-R primers (Figure S4). Southern blot performed on three randomly chosen plants with complete excision confirmed that these did not have the kanamycin resistance $n p t I I$ gene (Fig. 5).

\section{Discussion}

The present work aimed at obtaining PLRV resistant potato plants without an antibiotic resistance gene using RNAi (Waterhouse et al. 1998) and a selfexcisable Cre-loxP nptII system respectively (Cuellar et al. 2006). RNAi has been used successfully to confer resistance to several plant viruses (Mansoor 

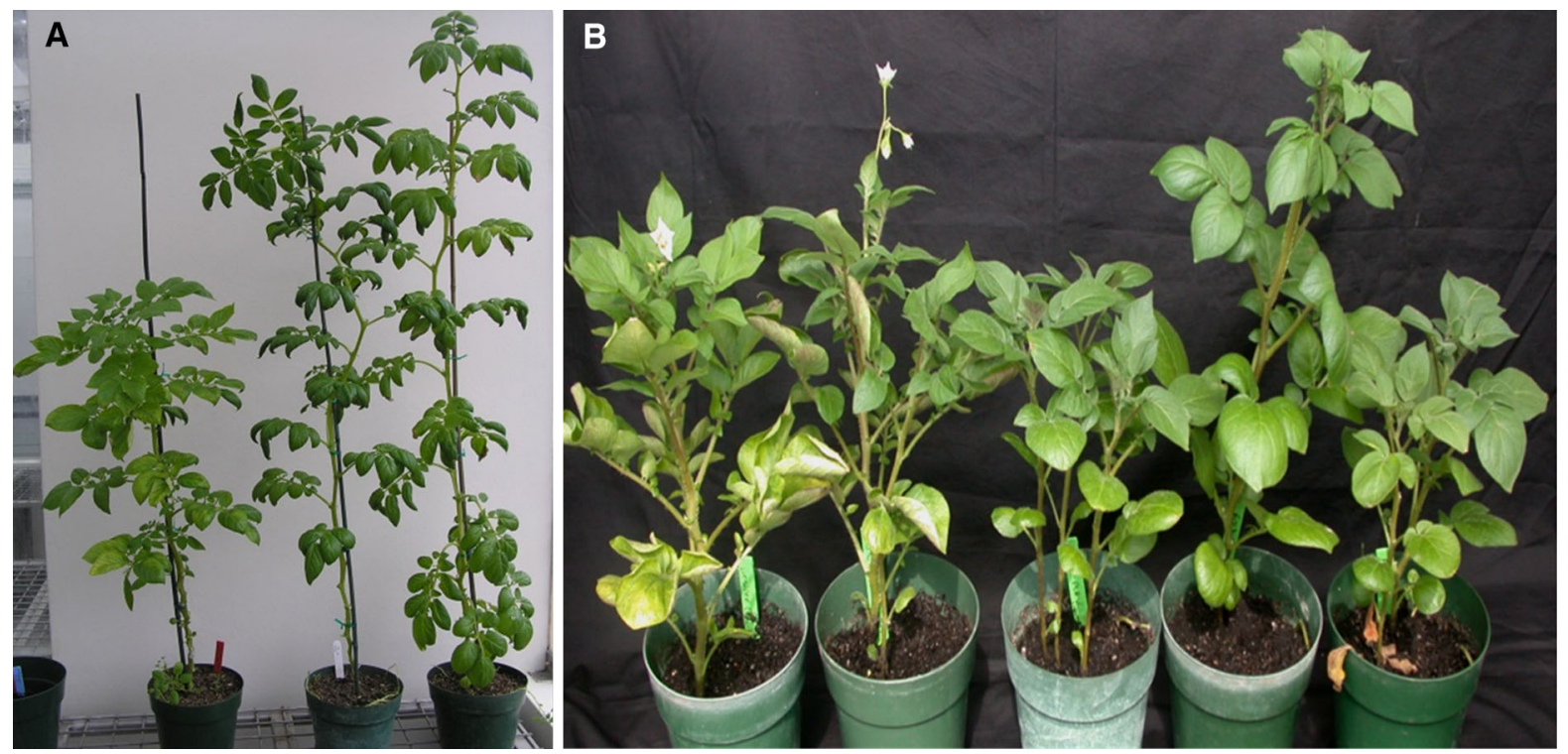

Fig. 3 a Symptoms of primary infection of PLRV at 60 days post inoculation, from left to right: non-transgenic Desiree, resistant event 68, and non-inoculated Desiree. b Symptoms of secondary infection of PLRV 30 days post planting of tubers of graft inoculated mother plants, from left to right: non-transgenic Desiree, event 40 (non-resistant), event 34 (resistant), event 54 (resistant), and non-inoculated Desiree

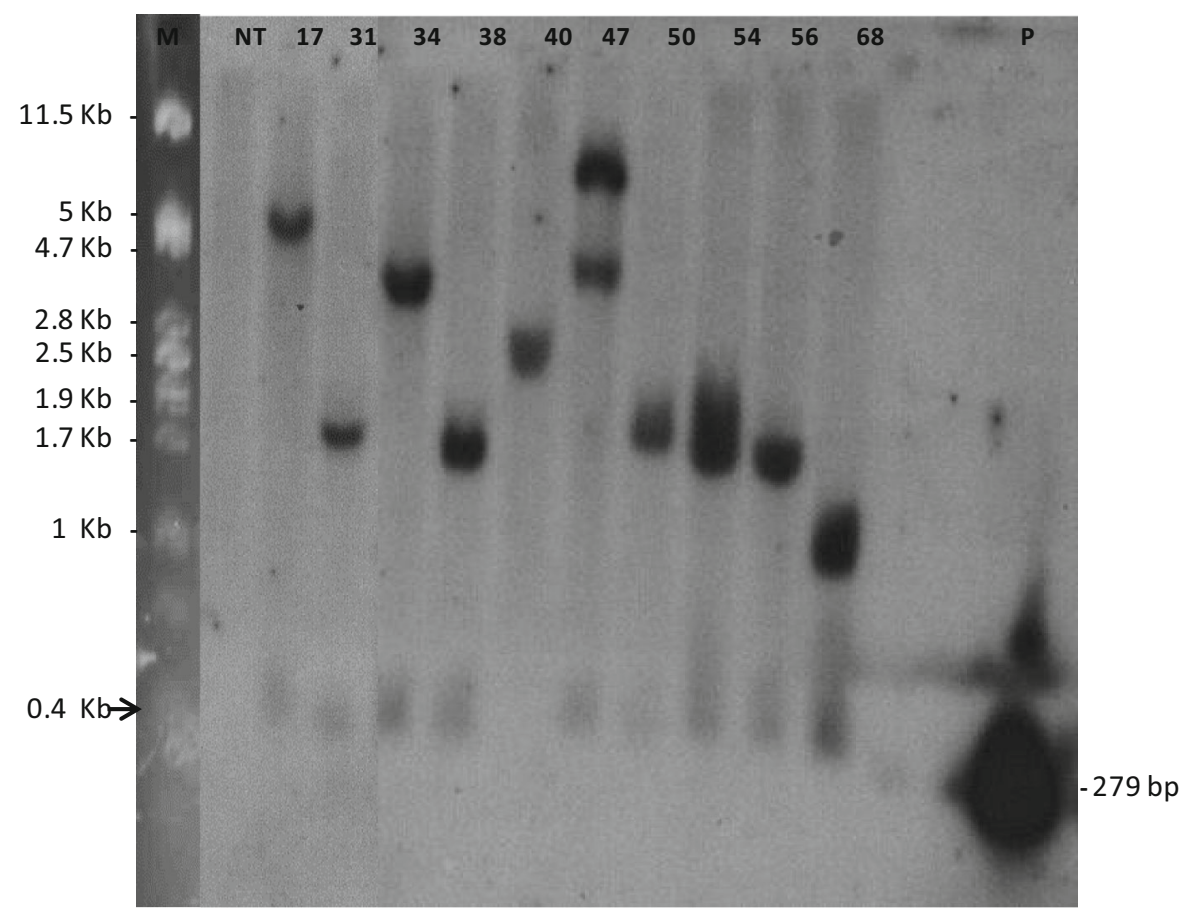

Fig. 4 Southern-blot analysis of genomic DNA of the ten best transgenic events. DNA was digested with EcoRI and hybridized with a probe corresponding to the coat protein $\mathrm{CP}$ of PLRV, resulting in two bands, one corresponding to the $400 \mathrm{bp}$ fragment from sense arm of the CP hairpin (indicated by the arrow), and another of variable size corresponding to the antisense arm of the hairpin up to the next restriction site at the insertion site in the potato DNA. M: $\lambda$ DNA (Gibco-BRL) digested with PstI, NT: Non-transgenic var. Desiree, P: Probe coat protein (CP) of PLRV (279 bp). One lane containing a duplicated sample 34 was removed electronically from the presented figure between current lanes with samples 31 and 34 
et al. 2006; Smith et al. 2000; Tenllado et al. 2004) including as PLRV (Arif et al. 2012; Chung et al. 2013). One important criteria is to choose the hairpin sequence with at least $90 \%$ nucleotide identity to the targeted virus (de Haan et al. 1992). Hence, we chose a region of coat protein in the PLRV genome with the least sequence variation in PLRV sequences deposited in GenBank.

50 out of 54 (93\%) of transgenic events showed a recovery phenotype during primary infection: initially significant virus titers reduced during plant maturity resulting in mostly ELISA-negative plants at 90 dpi. The recovery phenotype, typified by initially symptomatic plants recovering from virus infection, is not uncommon among transgenic plants, and it has also previously been observed in PLRV transgenic plants (Ehrenfeld et al. 2004). Recovery was not observed in secondary infection, which is concurrent with the notion that infection is always more severe in plants obtained from infected tubers. In all but ten events virus titers resurged during secondary infection and most plants did not recover, indicating that resistance was not sufficient to suppress the more severe secondary infection in these events. The same was observed in the second experiment using the ten best events: most of the transgenic lines remained completely symptom-less and with low virus titers during primary infection in contrast to the control, indicating they possessed some level of resistance. Only line 40 displayed some symptoms, and correspondingly had similarly high titers as the control at 60 and $90 \mathrm{dpi}$ (Figure S1). During secondary infection however, only four events $(34,54,56$ and 68) never showed symptoms, and remained entirely ELISA negative

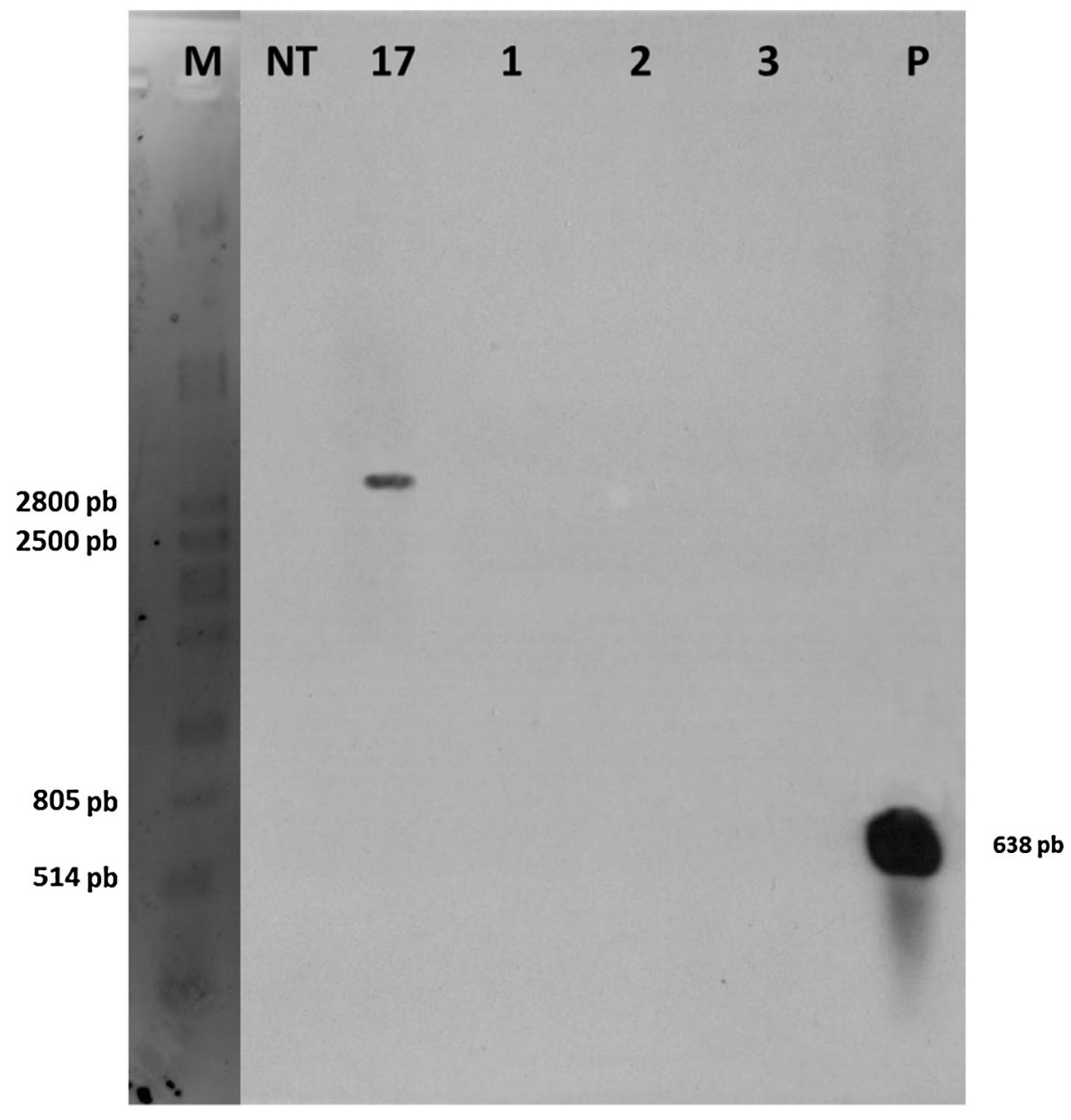

Fig. 5 Southern blot analysis of marker excision. M: $\lambda$ DNA (Gibco-BRL) digested with PstI. NT: non-transformed var. Desiree, 17: transgenic event 17 without heat-shock treatment, lanes $1-3$ : event 17 after heat-shock treatment at $40{ }^{\circ} \mathrm{C}$ for $3 \mathrm{~h}, P$ : probe $n p t \mathrm{II}$ gene 
during secondary infection. Because events 40 and 47 became highly symptomatic and had viral titers similar to the non-transgenic control, it seems that the level of resistance is not necessarily stable in all events, as events 40 and 47 which were selected based on their resistance in the first experiment.

At first it may seem surprising that such a limited number of plants displayed an immune phenotype as several reports indicate a high number of transgenic events providing immunity using similar technology (Kalantidis et al. 2002; Missiou et al. 2004; Smith et al. 2000). However upon closer inspection of the literature it appears that the highest efficiencies are obtained for resistance to potyviruses, and that in the attempts to engineer resistance to luteoviruses (Tougou et al. 2006; Wang et al. 2000), full immunity has never been demonstrated, while number of resistant plants among the transformants was much lower (Chung et al. 2013; Wang et al. 2000). Moreover, as the other crops, previously engineered for luteovirus resistance were seed propagated, clonal generations are irrelevant and were not evaluated. It may be possible that much higher resistance levels are required to control luteoviruses over clonal generations; indeed, even in the best NewLeaf varieties virus infection became detectable in progeny plants from tubers produced from field inoculated plants in which virus was undetectable (Thomas et al. 2000). This was not tested in any of the other reports on transgenic PLRV resistance.

siRNAs were detected by northern blot in all ten selected events except for the most susceptible one (40), and relative amounts were positively correlated with the level of resistance, i.e. the most resistant events had the strongest siRNA signal (Fig. 2). A similar observation in terms of quantities of siRNA was reported by Missiou et al. (2004). Interestingly, siRNAs corresponding to the PLRV CP region could not be detected in non-transgenic plants infected with PLRV. This may be due to PLRV being phloem limited; phloem cells only representing $\sim 1 \%$ of all plant cells and thus if siRNA is produced exclusively in infected cells, their overall quantity may fall below the detection limit, even if they were relatively abundant within those cells. Indeed, we have found PLRV derived siRNAs can be readily detected from infected potato plants by high throughput sequencing, although their relative amounts are extremely low in comparison to other viruses that are not phloem limited such as PVY or PVX (data not shown). The lack of siRNA detected in event 40 is consistent with our inability to detect one of the inverted repeats of the $\mathrm{CP}$ hairpin structure.

Upon analyzing, by PCR, the integrity of the T-DNA sequences present in the ten selected events, we were surprised to find that nearly all of them were truncated in their LB region, and that all but two of them had even lost the left loxP site. Indeed, original attempts to excise the Cre-nptII cassette in the most resistant events $(34,54,56$ and 68) failed to provide any kanamycin susceptible regenerants (data not shown). The truncation of the T-DNA fragment before the left $\operatorname{lox} P$ site was further confirmed by genome walking and sequencing in two of the resistant events, which were able to identify the exact position at which each of them were truncated, about $1200 \mathrm{bp}$ downstream of the LB sequences. Similar large deletions of 900 and $1500 \mathrm{bp}$ have been reported in other studies (Gambino et al. 2009; Tinland 1996) and may be due to the micro-similarities between the T-DNA sequence and the plant genome toward the LB (Gambino et al. 2009), rearrangements during the T-DNA integration (Kohli et al. 2003; Nacry et al. 1998). Indeed, it is known that integration of the LB is less exact during T-DNA insertion into the genome as compared to RB sequence (Meng et al. 2007; Zhang et al. 2008). Whatever the reason, such a high frequency of truncated insertions is undesirable because it renders most transformed events unsuitable for marker gene excision. Improvement of the pCIP35 vector by removing unnecessary sequences so that the loxP site tightly follows the nptII gene should be able to strongly reduce such truncations effectively.

Transgenic plants which use Cre-loxP system can produce different excision results such as complete (Gilbertson 2003), chimerics (Tuteja et al. 2012; Zuo et al. 2001) or no excision at all (Li et al. 2007), and we found similar results in our study. Using this system we obtained $71 \%$ excision efficiency, which is considerably higher to the $4-8 \%$ of excision previously obtained by Cuellar et al. (2006) who used the same backbone construct. Thus we believe that CreloxP system is an effective mechanism in contrast to selection without marker gene, which is consider very laborious (Bukovinszki et al. 2007) and not efficient (Kumar and Thompson 2009).

In conclusion, we obtained seven events with increased resistant to PLRV, of which four were 
extremely resistant. This demonstrates extremely high levels of resistance can also be obtained against luteoviruses such as PLRV, which is maintained also over tuber generations, something that had not been demonstrated before. Whereas analysis of the integration sites revealed that most T-DNA insertions had been truncated towards their LB, thereby losing one of the $\operatorname{lox} P$ sites, highly efficient heat shock mediated excision from resistant event 17 , which contained both flanking loxP sites, was demonstrated. Thus, if the issue of undesirable truncation of the transgene cassette, by eliminating unnecessary sequences in the nptII gene and the left loxP site, can be resolved, the pCIP35 vector would provide an excellent vector for selectable marker free introduction of PLRV resistance into susceptible potato varieties. The level of resistance to PLRV in this study was correlated to production of siRNAs in the transgenic plants, thus our data suggest preliminary screening of events based on siRNA production could be applied to rapidly select candidate resistant events for virus inoculation in field or greenhouse. On the other hand, the PLRV resistant Desiree event 17 , lacking nptII generated in this study is now a candidate to be evaluated for resistance to PLRV under field conditions and could be used to add additional traits of interest by transgenesis.

Acknowledgments Felipe de Mendiburu is acknowledge for help in statistical analysis, and Alberto Baiocchi for technical assistance. This work was funded by the CGIAR research program on Roots, Tubers and Bananas.

Open Access This article is distributed under the terms of the Creative Commons Attribution 4.0 International License (http:// creativecommons.org/licenses/by/4.0/), which permits unrestricted use, distribution, and reproduction in any medium, provided you give appropriate credit to the original author(s) and the source, provide a link to the Creative Commons license, and indicate if changes were made.

\section{References}

Alimentarius C (2003) Codex principles and guidelines on foods derived from biotechnology. Food and Agric Organ, Rome

An S et al (2003) Generation and analysis of end sequence database for T-DNA tagging lines in rice. Plant Physiol 133:2040-2047

Arif M, Azhar U, Arshad M, Zafar Y, Mansoor S, Asad S (2012) Engineering broad-spectrum resistance against RNA viruses in potato. Transgenic Res 21:303-311

Bai Y, Guo Z, Wang X, Bai D, Zhang W (2009) Generation of double-virus-resistant marker-free transgenic potato plants. Prog Nat Sci 19:543-548
Barker H, Dale MFB (2006) Resistance to viruses in potato. In Natural resistance mechanisms of plants to viruses, Springer, Berlin, pp 341-366

Barker H, Harrison B (1986) Restricted distribution of potato leafroll virus antigen in resistant potato genotypes and its effect on transmission of the virus by aphids. Ann Appl Biol 109:595-604

Barker H, Waterhouse P (1999) The development of resistance to luteoviruses mediated by host genes and pathogenderived transgenes. The Luteoviridae CAB International, Wallingford, pp 169-210

Barker H, Reavy B, Kumar A, Webster KD, Mayo MA (1992) Restricted virus multiplication in potatoes transformed with the coat protein gene of potato leafroll luteovirus: similarities with a type of host gene-mediated resistance. Ann Appl Biol 120:55-64. doi:10.1111/j.1744-7348.1992. tb03403.x

Barker H, Webster KD, Jolly CA, Reavy B, Kumar A, Mayo MA (1994) Enhancement of resistance to potato leafroll virus multiplication in potato by combining the effects of host genes and transgenes. Mol Plant Microbe Interact 7:528-530

Bukovinszki Á, Divéki Z, Csányi M, Palkovics L, Balázs E (2007) Engineering resistance to PVY in different potato cultivars in a marker-free transformation system using a 'shooter mutant'A. tumefaciens. Plant Cell Rep 26:459-465

Chung BN, Yoon J-Y, Palukaitis P (2013) Engineered resistance in potato against potato leafroll virus, potato virus $\mathrm{A}$ and potato virus Y. Virus Genes 47:86-92

Cuellar W et al (2006) Self-excision of the antibiotic resistance gene nptII using a heat inducible Cre-loxP system from transgenic potato. Plant Mol Biol 62:71-82

Cullen D, Harwood W, Smedley M, Davies H, Taylor M (2011) Comparison of DNA walking methods for isolation of transgene-flanking regions in GM potato. Mol Biotechnol 49:19-31

Dale EC, Ow DW (1991) Gene transfer with subsequent removal of the selection gene from the host genome. Proc Natl Acad Sci 88:10558-10562

Darbani B, Eimanifar A, Stewart CN, Camargo WN (2007) Methods to produce marker-free transgenic plants. Biotechnol J 2:83-90

Davidson T (1973) Assessing resistance to leafroll in potato seedlings. Potato Res 16:99-108

de Haan P et al (1992) Characterization of RNA-mediated resistance to tomato spotted wilt virus in transgenic tobacco plants. Nat Biotechnol 10:1133-1137

Ehrenfeld N, Romano E, Serrano C, Arce-Johnson P (2004) Replicase mediated resistance against Potato Leafroll Virus in potato Desirée plants. Biol Res 37:71-82. doi:10. 4067/S0716-97602004000100008

Fladung M, Nowitzki O, Kumar S, Hoenicka H (2005) The sitespecific recombination systems Cre-lox and FLP-FRT are also active in popular. For Genet 12:121

Gambino G, Chitarra W, Maghuly F, Laimer M, Boccacci P, Marinoni DT, Gribaudo I (2009) Characterization of T-DNA insertions in transgenic grapevines obtained by Agrobacterium-mediated transformation. Mol Breed 24:305-320

Gilbertson L (2003) Cre-lox recombination: cre-ative tools for plant biotechnology. Trends Biotechnol 21:550-555 
Graham MW, Craig S, Waterhouse PM (1997) Expression patterns of vascular-specific promoters RolC and Sh in transgenic potatoes and their use in engineering PLRVresistant plants. Plant Mol Biol 33:729-735. doi:10.1023/ A: 1005726918110

Hare PD, Chua N-H (2002) Excision of selectable marker genes from transgenic plants. Nat Biotechnol 20:575-580

Harrison B (1958) Studies on the behavior of potato leaf roll and other viruses in the body of their aphid vector Myzus persicae (Sulz.). Virology 6:265-277

Hoess R, Abremski K (1990) The Cre-lox recombination system. In: Eckstein F, Lilley D (eds) Nucleic acids and molecular biology. Springer, Berlin, pp 99-109

Hoff T, Schnorr KM, Mundy J (2001) A recombinase-mediated transcriptional induction system in transgenic plants. Plant Mol Biol 45:41-49

Hood EE, Gelvin SB, Melchers LS, Hoekema A (1993) New Agrobacterium helper plasmids for gene transfer to plants. Transgenic Res 2:208-218

Kalantidis K, Psaradakis S, Tabler M, Tsagris M (2002) The occurrence of CMV-specific short RNAs in transgenic tobacco expressing virus-derived double-stranded RNA is indicative of resistance to the virus. Mol Plant Microbe Interact 15:826-833

Kawchuk L, Martin R, McPherson J (1990) Resistance in transgenic potato expressing the potato leafroll virus coat protein gene. Mol Plant Microbe Interact 3:301-307

Khattri A, Nandy S, Srivastava V (2011) Heat-inducible Cre-lox system for marker excision in transgenic rice. J Biosci $36: 37-42$

Kohli A, Twyman RM, Abranches R, Wegel E, Stoger E, Christou P (2003) Transgene integration, organization and interaction in plants. Plant Mol Biol 52:247-258

Kreuze JF, Savenkov EI, Cuellar W, Li X, Valkonen JPT (2005) Viral Class 1 RNase III involved in suppression of RNA silencing. J Virol 79:7227-7238. doi:10.1128/JVI.79.11. 7227-7238.2005

Kruskal WH, Wallis WA (1952) Use of ranks in one-criterion variance analysis. J Am Stat Assoc 47:583-621

Kumar S, Thompson WF (2009) Simultaneous excision of two transgene flanking sequences and resolution of complex integration loci. Plant Mol Biol 69:23-32

Latham JR, Wilson AK (2008) Transcomplementation and synergism in plants: implications for viral transgenes? Mol Plant Pathol 9:85-103. doi:10.1111/j.1364-3703.2007. 00441.x

Lemgo GNY, Sabbadini S, Pandolfini T, Mezzetti B (2013) Biosafety considerations of RNAi-mediated virus resistance in fruit-tree cultivars and in rootstock. Transgenic Res 22:1073-1088

Li Z et al (2007) A Cre/loxP-mediated self-activating gene excision system to produce marker gene free transgenic soybean plants. Plant Mol Biol 65:329-341

Liu H-K, Yang C, Wei Z-M (2005) Heat shock-regulated sitespecific excision of extraneous DNA in transgenic plants. Plant Sci 168:997-1003

Mansoor S, Amin I, Hussain M, Zafar Y, Briddon RW (2006) Engineering novel traits in plants through RNA interference. Trends Plant Sci 11:559-565

McHughen A, Smyth S (2008) US regulatory system for genetically modified [genetically modified organism
(GMO), rDNA or transgenic] crop cultivars. Plant Biotechnol J 6:2-12

Meng Y et al (2007) A systematic analysis of T-DNA insertion events in Magnaporthe oryzae. Fungal Genet Biol 44:1050-1064

Mihovilovich E, Aponte M, Lindqvist-Kreuze H, Bonierbale M (2014) An RGA-derived SCAR marker linked to PLRV resistance from Solanum tuberosum ssp. andigena. Plant mol biol report 32:117-128

Miki B, McHugh S (2004) Selectable marker genes in transgenic plants: applications, alternatives and biosafety. J Biotechnol 107:193-232

Missiou A, Kalantidis K, Boutla A, Tzortzakaki S, Tabler M, Tsagris M (2004) Generation of transgenic potato plants highly resistant to potato virus Y (PVY) through RNA silencing. Mol Breeding 14:185-197. doi:10.1023/B: MOLB.0000038006.32812.52

Mowry TM (2005) Insecticidal reduction of Potato leafroll virus transmission by Myzus persicae. Ann Appl Biol 146:81-88

Nacry P, Camilleri C, Courtial B, Caboche M, Bouchez D (1998) Major chromosomal rearrangements induced by T-DNA transformation in Arabidopsis. Genetics 149: 641-650

Novy R, Gillen A, Whitworth J (2007) Characterization of the expression and inheritance of potato leafroll virus (PLRV) and potato virus $\mathrm{Y}$ (PVY) resistance in three generations of germplasm derived from Solanum etuberosum. Theor Appl Genet 114:1161-1172

Paoletti MG, Pimentel D (2000) Environmental risks of pesticides versus genetic engineering for agricultural pest control. J Agric Environ Ethics 12:279-303

Puchta H (2003) Marker-free transgenic plants. Plant Cell Tissue Organ Cult 74:123-134

Radcliffe EB, Ragsdale DW (2002) Aphid-transmitted potato viruses: the importance of understanding vector biology. Am J Potato Res 79:353-386

Ramessar K et al (2007) Biosafety and risk assessment framework for selectable marker genes in transgenic crop plants: a case of the science not supporting the politics. Transgenic Res 16:261-280

Sambrook J, Russell DW (2001) Molecular cloning. A laboratory manual. Third. Cold pring Harbor Laboratory Press, New York

Scutt CP, Zubko E, Meyer P (2002) Techniques for the removal of marker genes from transgenic plants. Biochimie 84:1119-1126

Sessions A et al (2002) A high-throughput Arabidopsis reverse genetics system. Plant Cell 14:2985-2994. doi:10.1105/ tpc. 004630

Smith NA, Singh SP, Wang M-B, Stoutjesdijk PA, Green AG, Waterhouse PM (2000) Gene expression: total silencing by intron-spliced hairpin RNAs. Nature 407:319-320

Svitashev S, Ananiev E, Pawlowski W, Somers D (2000) Association of transgene integration sites with chromosome rearrangements in hexaploid oat. Theor Appl Genet 100:872-880

Syller J (1996) Potato leafroll virus (PLRV): its transmission and control. Integr Pest Manag Rev 1:217-227

Sylvester E (1980) Circulative and propagative virus transmission by aphids. Annu Rev Entomol 25:257-286 
Taliansky M, Mayo MA, Barker H (2003) Potato leafroll virus: a classic pathogen shows some new tricks. Mol Plant Pathol 4:81-89. doi:10.1046/j.1364-3703.2003.00153.x

Tenllado F, Llave C, Díaz-Ruiz JR (2004) RNA interference as a new biotechnological tool for the control of virus diseases in plants. Virus Res 102:85-96. doi:10.1016/j.virusres. 2004.01.019

Thomas CM, Jones JD (2007) Molecular analysis of Agrobacterium T-DNA integration in tomato reveals a role for left border sequence homology in most integration events. Mol Genet Genomics 278:411-420

Thomas P, Kaniewski W, Lawson E (1997) Reduced field spread of potato leafroll virus in potatoes transformed with the potato leafroll virus coat protein gene. Plant Dis 81:1447-1453

Thomas PE, Lawson EC, Zalewski JC, Reed GL, Kaniewski WK (2000) Extreme resistance to Potato leafroll virus in potato cv. Russet Burbank mediated by the viral replicase gene. Virus Res 71:49-62. doi:10.1016/S0168-1702(00)00187-8

Tinland B (1996) The integration of T-DNA into plant genomes. Trends Plant Sci 1:178-184

Tougou M, Furutani N, Yamagishi N, Shizukawa Y, Takahata Y, Hidaka S (2006) Development of resistant transgenic soybeans with inverted repeat-coat protein genes of soybean dwarf virus. Plant Cell Rep 25:1213-1218. doi:10. 1007/s00299-006-0186-6

Tuteja N, Verma S, Sahoo RK, Raveendar S, Reddy IBL (2012) Recent advances in development of marker-free transgenic plants: regulation and biosafety concern. J Biosci 37:167-197
Vancanneyt G, Schmidt R, O'Connor-Sanchez A, Willmitzer L, Rocha-Sosa M (1990) Construction of an intron-containing marker gene: splicing of the intron in transgenic plants and its use in monitoring early events in Agrobacterium-mediated plant transformation. Mol Gen Genet 220:245-250

Velásquez A, Mihovilovich E, Bonierbale M (2007) Genetic characterization and mapping of major gene resistance to potato leafroll virus in Solanum tuberosum ssp. andigena. Theor Appl Genet 114:1051-1058

Wang M-B, Abbott DC, Waterhouse PM (2000) A single copy of a virus-derived transgene encoding hairpin RNA gives immunity to barley yellow dwarf virus. Mol Plant Pathol 1:347-356. doi:10.1046/j.1364-3703.2000.00038.x

Waterhouse PM, Graham MW, Wang M-B (1998) Virus resistance and gene silencing in plants can be induced by simultaneous expression of sense and antisense RNA. Proc Natl Acad Sci 95:13959-13964. doi:10.1073/pnas.95.23. 13959

Waterhouse PM, Wang M-B, Lough TJ (2001) Gene silencing as an adaptive defence against viruses. Nature 411:834-842

Zhang W, Subbarao S, Addae P, Shen A, Armstrong C, Peschke V, Gilbertson L (2003) Cre/lox-mediated marker gene excision in transgenic maize (Zea mays L.) plants. Theor Appl Genet 107:1157-1168

Zhang J et al (2008) Transgene integration and organization in Cotton (Gossypium hirsutum L.) genome. Transgenic Res 17:293-306. doi:10.1007/s11248-007-9101-3

Zuo J, Niu Q-W, Møller SG, Chua N-H (2001) Chemical-regulated, site-specific DNA excision in transgenic plants. Nat Biotechnol 19:157-161 